\title{
STRATEGI MANAJEMEN PENGELOLAAN WAKAF PRODUKTIF DI PESANTREN YAYASAN ARWANIYYAH KUDUS
}

\author{
M Bastomi Fahri \\ Mahasiswa Program Studi S1 Ekonomi Islam-Fakultas Ekonomi dan Bisnis-Universitas Airlangga \\ Email : bastomi.fahri-13@feb.unair.ac.id \\ Irham Zaki \\ Departemen Ekonomi Syariah-Fakultas Ekonomi dan Bisnis-Universitas Airlangga \\ Email: irham.zaki@feb.unair.ac.id
}

Basically, waqf only have a direct function. Islamic boarding school didn't yet to productive the land of wagf. Yayasan Arwaniyyah is a foundation with boarding school basic who can utilizing wagf land productively.

This study aims to describe the manajement of wagf productif in Yayasan Arwaniyyah Kudus. This study is using qualitative approach with study case strategy. Analitical technique is based on theoritical preposition, that followed the theoritical preposition which guide the case of study. Arwaniyyah Foundation when utilize the wagf productive do several things, which is performing management fungtions in the implemetation of waqf productive, creating jobs and social care, and creating economic independence boarding school.

The result of this research show that Arwaniyyah Foundation utilize lands wagf to be productive to achieve economic independence boarding school. Management of wagf conducted by the foundation divided into three areas. Religion activities, Islamic education, and social and economic.

\section{Keyword: Waqf Productive, Manajement, Islamic Boarding School.}

\section{Pendahuluan}

\section{Latar Belakang}

Penerapan konsep ekonomi syariah di Indonesia begitu gencar dan bergerak cepat dewasa ini. Kegiatan-kegiatan muamalah ataupun keuangan dengan basis syariah dilakukan dimana-mana, bahkan sampai ke kota-kota besar yang notabene maju dalam sistem-sistem konvensional. Hal itu muncul karena menyikapi masalah-masalah yang muncul di masyarakat, terutama pada masalah ekonomi dan sosial masyarakat, seperti masalah kemereataan pendapatan dan pembangunan ekonomi masyarakat. Ekonomi Islam dalam hal ini memiliki banyak solusi untuk mengatasi masalahmasalah ekonomi tersebut, salah satunya dengan wakaf. Dengan adanya lembaga wakaf yang profesional menjadi sebuah strategi yang baik dalam pembangunan ekonomi umat.

Secara khusus Al Qur'an tidak menyebutkan tentang wakaf. Di dalam Al Qur'an hanya disebutkan sebagai shadaqah/infaq seperti di dalam surat Al Imran ayat 92 :

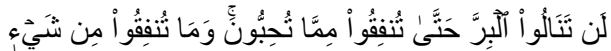

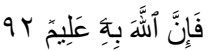

Artinya : Kamu sekali-sekali tidak sampai kepada kebajikan sehingga menginfakkan sebagian harta yang engkau cintai, dan apa saja yang engkau nafkahkan, maka sesungguhnya Allah mengetahuinya (Q.S. Al Imran: 92).

Jaih Mubarok (2008: 28), wakaf produktif dikelola dengan pendekatan 
Fahri, et al/Jurnal Ekonomi Syariah Teori dan Terapan Vol. 5 No. 8 Agustus 2018: 695-708;

\section{STRATEGI MANAJEMEN}

bisnis, yakni suatu usaha yang beorientasi pada keuntungan dan keuntungan tersebut disedekahkan pada yang berhak menerima. Pemberdayaan wakaf produktif ini selain berorientasikan pada laba atau keuntungan juga memberikan manfaat ekonomi maupun sosial dari keuntungan tersebut.

Di Indonesia kegiatan wakaf produktif masih tergolong kegiatan baru, terutama di kalangan pondok pesantren. Walaupun selama ini pesantren merupakan institusi Islam yang sangat terkait dengan kegiatan wakaf. Baru dewasa ini kegiatan wakaf produktif begitu gencar dicanangkan di Indonesia.

Secara historis pesantren telah memberikan andil besar bagi kemajuan peradaban Islam di Indonesia, baik itu secara kultural, sosial, maupun ekonomi masyarakat Indonesia. Sejak awal penyebaran Islam, pesantren mampu membawa perubahan besar terhadap persepsi halayak nusantara tentang arti penting agama dan pendidikan (Mujib 2007 dalam Saadati 2014:12).

Pesantren sebagai lembaga pendidikan yang memiliki akar kuat pada masyarakat muslim Indonesia, dalam perjalanannya selama ini mampu bertahan dan menjaga kelangsungan hidup system yang dijalani. Di Indonesia terdapat ribuan lembaga pendidikan yang berbasis pesantren. Menurut data yang terkumpul pada Kementian Agama Republik Indonesia terdapat 3.719 Pesantren yang tersebar di provinsi Jawa Tengah. Sedangkan untuk Kabupaten
Kudus sendiri ada 111 pondok pesantren yang tersebar. Hal ini menunjukkan bahwa pendidikan dengan sistem pesantren masih begitu kental dirasakan oleh masyarakat Indonesia. Menurut Kementrian Agama Republik Indonesia juga, tanah wakaf di Indonesia tercatat seluas 4,2 miliar meter persegi di 42.300 lokasi.

Yayasan Arwaniyyah Kudus dikenal sebagai lembaga pendidikan pesantren salafiyyah yang fokus dalam pengkaderan santri-santri penghafal Al Qur'an. Namun, selain itu, Yayasan yang berada di kota Kudus, Jawa Tengah selama ini secara professional juga mengelola tanah wakaf menjadi sesuatu yang produktif dan bermanfaat tidak hanya bagi pesantren tetapi juga bagi masnyarakat sekitar. Penelitian ini memilih Yayasan Arwaniyyah menjadi objek penilitian karena yayasan ini menjadi percontohan oleh Kementrian Agama kabupaten Kudus dan Badan Wakaf Indonesia kabupaten Kudus sebagai yayasan berbasis pesantren yang mampu mengelola aset wakaf menjadi lebih produktif (nu.or.id) Yayasan Arwaniyyah mengelola berbagai bidang di beberapa sektor, yaitu pada sektor Agama, Pendidikan, dan Sosial dan Ekonomi.

Berdasarkan uraian diatas, dapat ditarik sebuah kesimpulan bahwa wakaf produktif dapat memberikan kemaslahatan bagi umat terutama pada sektor ekonomi dan sosial. Wakaf produktif dinilai dapat menjadikan solusi bagi potensi-potensi ekonomi umat yang 
Fahri, et al/Jurnal Ekonomi Syariah Teori dan Terapan Vol. 5 No. 8 Agustus 2018: 695-708; STRATEGI MANAJEMEN PENGELOLAAN WAKAF PRODUKTIF DI PESANTREN YAYASAN ARWANIYYAH KUDUS

selama ini belum tergali, khususnya

meningkatkan

kemandirian

didaerah pesantren.

Mengenai hal ini peneliti ingin ekonomi pesantren.

\section{LANDASAN TEORI}

meneliti sebuah Yayasan Islam yang memiliki daya tarik di bidang pesantren dan usaha ekonomi umat di daerah Kudus Jawa Tengah. Peneliti melihat adanya potensi yang dikembangkan oleh yayasan Arwaniyyah ini dalam mengelola asset wakaf secara optimal. Dengan uraian tersebut penulis menulis sebuah skripsi dengan judul "Strategi Manajemen Pengelolaan Wakaf Produktif di Pesantren Yayasan Arwaniyyah".

\section{Rumusan Masalah}

Agar peneliti dapat menuju arah tujuan penelitian yang dicapai, maka harus ada rumusan masalah dari penelitian itu. Adanya rumusan masalah tersebut diharapkan dapat menghindari kesimpangsiuran dan ketidakkonsistensi dalam penulisan penelitian.

Berdasarkan latar belakang yang telah peneliti uraikan sebelumnya, maka peneliti memberikan rumusan masalah sebagai berikut :

1. Bagaimanapen strategi pengelolaan wakaf produktif di Pesantren Yayasan Arwaniyyah Kudus?

\section{TUJUAN}

1. Untuk mengetahui manajemen wakaf produktif dilingkungan pesantren Yayasan Arwaniyyah Kudus.

2. Untuk memahami pelaksanaan wakaf produktif dalam

\section{Pengertian Wakaf}

Kegiatan wakaf saat ini sudah tidak asing lagi terdengar di masyarakat. Kata wakaf berasal dari bahasa Arab "Waqofa", selain itu juga memiliki kesamaan kata dengan "Habasa". Kedua kata tersebut memiliki arti menahan. Ia merupakan kata berbentuk masdar yang kata dasarnya meimiliki arti menahan, berhenti, dan diam. Apabila kata tersebut dihubungkan dengan harta seperti tanah ia berarti pembekuan hak milik untuk faedah tertentu.(Al Bajuri 2/42)

Secara istilah syar'i wakaf memiliki arti sebagai berikut (Ibrohim Al Bajuri : 2/42):

Menahan harta tertentu yang hanya diambil manfaatnya dari harta tersebut dengan membiarkan bendanya dan meninggalkannya pada jalan kebaikan semata-mata untuk mendekatkan diri pada Allah.

\section{Dasar Hukum Wakaf}

Semua ketentuan syariat yang berkaitan dengan masalah ibadah maupun muamalat telah diatur sedemikian rupa oleh Al Qur'an dan Hadits, tak terkecuali masalah yang berkaitan dengan kegiatan ekonomi umat seperti zakat, wakaf, infaq, dan shodaqah (Ziswaq). Di dalam Al Qur'an wakaf tidak disebut secara eksplisit dan terperinci. Al Qur'an hanya menerangkan betapa 
Fahri, et al/Jurnal Ekonomi Syariah Teori dan Terapan Vol. 5 No. 8 Agustus 2018: 695-708;

\section{STRATEGI MANAJEMEN PENGELOLAAN ARWANIYYAH KUDUS}

pentingnya menginfaqkan harta. Firman

Allah dalam surat Ali Imron ayat 92 :

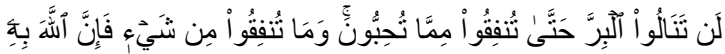

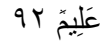

Artinya : Kamu tidak sekali-sekali mendaptka kebaikan hingga kalian menginfaqkan dari apa-apa yang kalian cintai. Maka sesungguhnya Allah maha mengetahui.

Adapun dasar hukum yang secara eksplisit menjelaskan tentang wakaf adalah hadits dari Nabi Muhammad SAW yang diriwayatkan oleh ibnu Umar r.a. di dalam kitab Shohih Muslim no 3085 :

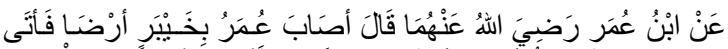

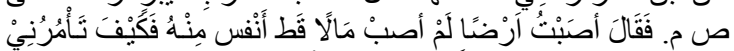

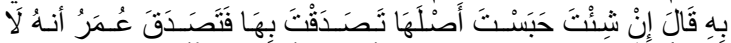

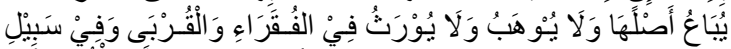

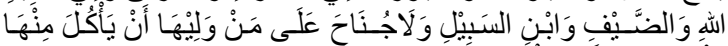

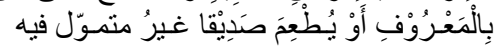

Artinya :Diriwayatkan dari Ibnu Umar RA berkata bahwa sahabat Umar bin Khattab RA memperoleh sebidang tanah khaibar, kemudian ia menghadap kepada Rosulullah SAW untuk memohon petunjuk. Umar RA berkata aku mendapatkan sebidang tanah, aku belum pernah mendapatkan harta sebaik ini sama sekali. Maka bagaimana yang akan engkau perintahkan wahai Rosulullah. Rosulullah SAW bersabda jika engkau menginginkan kamu tahan (pokoknya) dan kamu sedekahkan hasilnya. Kemudian umar menyedekahkan, tidak menjual pokoknya, tidak menghibahkan tidak juga mewariskan. Umar menyedekahkan kepada para fakir miskin, kaum kerabat, budak, sabilillah, ibnu sabil, dan tamu. Dan tidak mengapa bagi orang yang menguasai wakaf itu untuk memakan dari hasil wakaf itu dengan cara yang baik atau makan dengan maksud untuk menumpukkan harta. (H.R. Muslim 3085).

\section{Pengelolaan Wakaf Produktif}

Dahwan (2008:75) menyatakan diantara perjanjian-perjanjian (akad) yang ditawarkan dalam fikih mu'amalah dan kajian-kajian ekonomi Islam yang dapat digunakan untuk pengelolaan wakaf diantaranya :

1. Al ljarah

Al ljarah jika diartikan ke dalam bahasa Indonesia adalah sewamenyewa. Antonio (2001:117) mengutip pendapat Muhammad Rawas Qal'aji menyebutkan bahwa Al ljarah adalah akad pemindahan barang atau jasa, melalui pembayaran upah sewa tanpa diikuti dengan pemindahan kepemilikan (ownership) pada bang itu sendiri. Pada akad ini yang dimaksudkan adalah ljarah bil amwal atau wujud benda yang disewakan.

Pengelolaan wakaf produktif pada dengan model ljarah ini nadhir adalah pihak pertama yang menyewakan benda wakaf dan penyewa dari benda wakaf adalah pihak kedua yang dapat mengambil manfaat dari penyewaan benda wakaf. Penyewa melakukan kesepakatan dengan nadhir dalam masalah imbalan atas penyewaan benda wakaf yang dilakukan. Dahwan (2008:74)

2. Al ljarah Al A'mal 
Fahri, et al/Jurnal Ekonomi Syariah Teori dan Terapan Vol. 5 No. 8 Agustus 2018: 695-708;

\section{STRATEGI MANAJEM
ARWANIYYAH KUDUS}

Al ljarah al A'mal adalah akad antara pihak penyewa dan pihak yang disewa melakukan kegiatan sewa menyewa terhadap jasa tenaga kerja untuk melaksanakan suatu pekerjaan dengan upah atau gaji yang disepakati. Konsep seperti ini dapat dikatakan dengan perburuhan. Pengelolaan wakaf produktif dengan akad ini, nadhir adalah pihak yan menyewa tenaga kerja dan pihak lain merupakan orang yang melakukan pekerjaan atau disebut ajir. Antonio (2001:117)

\section{Al ljarah Muntahiyat bit Tamlik}

Menurut Syafi'i (2001:118) Al ljarah Muntahiyat bit Tamlik adalah perpaduan antara kontrak sewa menyewa dan jual beli. Sesuai dengan namanya akad ini merupakan akad sewa menyewa yang nantinya diakhiri dengan kepemilikan barang kepada penyewa. Akad seperti ini menjadi perbedaan dari akad ljarah biasa.

Pengelolaan wakaf produktif dengan metode akad seperti ini dapat dilakukan oleh nadhir bekerja sama dengan Bank Syariah atau dengan lembaga keuangan. Semisal seorang nadhir mengelola wakaf produktif berupa tanah untuk dimanfaatkan sebagai pabrik atau hotel. Nadhir bekerja sama dengan Bank Syariah untuk mendanai pembuatan pabrik atau hotel. Biaya sewa diansur oleh nadhir dari keuntungan produksi maupun penyewaan hotel. Setelah jatuh tempo dan selesai masa pembayaran sewa, maka bangunan tersebut dapat dimanfaatkan kembali sebagai wakaf.
4. Al Murabahah.

Akad Murabahah adalah jual beli barang pada harga asal dengan keuntungan yang disepakati oleh penjual dan pembeli. Dalam pengelolaan wakaf produktif, nadhir menjadi pembeli yang bekerja sama dengan Bank atau lembaga keuangan syariah lainnya. Nadhir membeli barangdengan sistem murabahah untuk dijadikan sebagai peralatan pengelolaan wakaf produktif. As Shan'ani (1960:216)

5. Al Musyarakah

Syafii (2001:90) menjelaskan pengertian Al Musyarakah adalah akad kerjasama antara dua belah pihak untuk suatu usaha tertentu dimana masingmasing pihak memberikan kontribusi dana dengan kesepakatan bahwa keuntungan dan resiko ditanggung bersama kedua belah pihak. Dahwan (2008:78) menyatakan jika dalam pegelolaan benda wakaf produktif, al musyarakah menjadi sebuah pilihan, maka nadhirakan berkedudukan sebagai salah satu pihak dalam penyelenggaraan perjanjian musyarakah ini. nadhir akan menyerahkan sebagian harta demikian pula pihak lain, untuk disatukan sebagai modal usaha.

\section{Al Mudharabah}

Menurut Ahmad As Syarbasyi dikutip oleh Syafi'i Antonio (2001:95) akad Al Mudharabah adalah akad kerjasama usaha antara dua pihak dimana pihak pertama (shohibul maal) menyediakan seluruh modal, dan pihak kedua (Mudhorib) menjadi pengelola usaha. Keuntungan usaha disepakati besaranya 
Fahri, et al/Jurnal Ekonomi Syariah Teori dan Terapan Vol. 5 No. 8 Agustus 2018: 695-708; STRATEGI MANAJEMEN PENGELOLAAN WAKAF PRODUKTIF DI PESANTREN YAYASAN

\section{ARWANIYYAH KUDUS}

oleh kedua pihak pada awal kontrak. Apabila dalam pengelolaannya mengalami kerugian, maka kerugian tersebut ditanggung oleh pemilik modal. Sedangkan jika kerugian diakibatkan oleh kelalaian dari pengelola, maka pengelola yang wajib bertanggung jawab atas kerugian yang terjadi.

\section{METODE PENELITIAN}

\section{Pendekatan Penelitian}

Pendekatan yang digunakan dalam penelitian ini adalah pendekatan kualitatif. Untuk menjawab rumusan masalah dengan kalimat pertanyaan "Bagaimana" tidak dibutuhkan jawaban yang berkaitan dengan perhitungan statitistik. Metode yang digunakan dalam penelitian kualitif ini atadalah studi kasus deskriptif yang mana pada penelitian ini digambarkan tentang bentuk pendayagunaan harta wakaf secara produktif yang dilakukan oleh nadhir di pesantren dengan mengambil kasus di Pesantren Yayasan Arwaniyyah Kudus.

\section{HASIL DAN PEMBAHASAN}

\section{Gambaran Umum Yayasan Arwaniyyah}

Yayasan Arwaniyyah berkedudukan di Jalan KH. M. Arwani no 24 Kelurahan Kajeksan Kota Kudus 59332, merupakan satu yayasan yang mengelola berbagai lembaga diatas tanah wakaf. Lembaga yang dikenal oleh masyarakat luas adalah pesantren Tahfidz Yanbu'ul Qur'an. (sumber: dokumen yayasan)

Yayasan Arwaniyyah disahkan melalui Akta No. 72 tahun 1987 Notaris Benjamin Kusuma, SH. Kemudian disesuaikan dengan Akta No. 41 tahun
1996 Notaris Benjamin Kusuma, SH. Kemudian disesuaikan UU Yayasan No.16/2001 dengan Akta no. 21 tahun 2007 Notaris Lianty Achwas, SH. perubahan terakhir dengan Akta No. 34 tahun 2006 Notaris Lianty Achwas, SH.

Yayasan Arwaniyyah merupakan yayasan berbasis pesantren yang bermanhajkan Ahlussunnah wal Jama'ah. Selain itu, dalam menjalankan kegiatan yang berkaitan dengan ibadah, mua'amalah maupun kegiatan-kegiatan pengajaran Yayasan Arwaniyyah mengikuti Madzhab Syafi'i. Yayasan ini mengelola lembaga pendidikan sejak awal pendiriannya dan selalu mendidik para santri untuk menjadi insan yang qur'aniy sebagai cita-cita yayasan.

Selain mengelola lembaga pendidikan sebagai lembaga utama yayasan Arwaniyyah juga mengelola lembaga lain yang bergerak di bidang sosial dan ekonomi. Lembaga-lembaga yang berada dibawah naungan yayasan Arwaniyyah antara lain:

A. Bidang Pendidikan

1. Jam'iyyah Thoriqoh Naqsabandiyah Kholidiyah yang berdiri sejak tahun 1950 dan memiliki anggota sekitar 20 ribu jama'ah

2. Jam'iyyah Huffadzil Qur'an.

3. Robithotul Huffadz Li Ma'had Yanbuul Qur'an.

4. Kelompok Bimbingan Ibadah Haji Arwaniyyah yang ratarata memiliki anggota pertahun 350-400 jama'ah 
Fahri, et al/Jurnal Ekonomi Syariah Teori dan Terapan Vol. 5 No. 8 Agustus 2018: 695-708; STRATEGI MANAJEMEN PENGELOLAAN WAKAF PRODUKTIF DI PESANTREN YAYASAN ARWANIYYAH KUDUS

5. Ikatan Haji Yayasan Hasil penelitian menunjukkan bahwa Arwaniyyah.

6. Pondok Pesantren Tahfidz Yanbu'ul Qur'an Dewasa (Putra)

7. Pondok Pesantren Tahfidz Yanbu'ul Qur'an Dewasa (Putri)

8. Pondok Tahfidz Yanbu'ul Qur'an Anak-Anak (Putra)

9. Pondok Tahfidz Yanbu'ul Qur'an Anak-anak (Putri)

10. Pondok Tahfidz Yanbu'ul Qur'an Remaja (Putra)

11. Pondok Pesantren MTs/MA Tahfidzul Qur'an Menawan, Gebog.

12. Ma'had Ulumus Syari'ah Yanbu'ul Qur'an (Putra)

13. Ma'had Ulumus Syari'ah yanbu'ul Qur'an (Putri)

B. Bidang Ekonomi

1. Toko dan Ruko

2. Koperasi Syariah

3. Arwaniyyah Tour dan Travel

4. Percetakan Arwaniyyah

5. Buya Barokah

C. Bidang Sosial

1. Klinik Pratama Al Fatah

2. Pos Pelayanan Kesehatan Pondok Pesantren

3. Pengelolaan Yatim Piatu

4. LAZIS Arwaniyyah.

\section{Deskripsi Hasil Penelitian}

Penelitian telah dilakukan di yayasan Arwaniyyah Kudus untuk mengetahui pengeloaan wakaf produktif yang dilakukan oleh yayasan Arwaniyyah. yayasan Arwaniyyah mengelola wakaf secra produktif untuk mencapai kemandirian ekonomi pesantren. Adapun penjelasan pengelolaan wakaf yang dilakukan oleh yayasan Arwaniyyah adalah sebagai berikut :

\section{Layanan Wakaf Yayasan Arwaniyyah}

Yayasan Arwaniyyah dalam menghimpun harta wakaf menggunakan layanan sebagai berikut:

1. Wakaf Tanah dan Bangunan Wakaf tanah dan bangunan merupakan aset wakaf yang sering dilakukan oleh wakif. Untuk melakukan wakaf tanah maka tanah yang akan diwakafkan haruslah jelas kepemilikannya. Pengelolaan aset wakaf tanah dan bangunan dapat dikelola untuk menjadi produktif seperti bangun-sewa ataupun kerjasama dengan pihak ketiga untuk pembuatan bisnis diatas aset wakaf.

2. Wakaf Bisnis dan Usaha

Wakaf bisnis dan usaha merupakan layanan yang diharapkan mampu memberikan maslahat bagi masyarakat luas. Adapun usah itu sendiri dapat berupa usaha layanan publik seperti sekolah, pondok pesantren, klinik. Serta ada usaha komersial seperti toko, ruko, dan kantor.

Pendistribusian Aset Wakaf Produktif 
Fahri, et al/Jurnal Ekonomi Syariah Teori dan Terapan Vol. 5 No. 8 Agustus 2018: 695-708; STRATEGI MANAJEMEN PENGELOLAAN WAKAF PRODUKTIF DI PESANTREN YAYASAN ARWANIYYAH KUDUS

Yayasan Arwaniyyah dalam mendayagunakan wakaf sesuai dengan visi dan misi yayasan maka terbagi ke dalam tiga lembaga, yaitu pendidikan, sosial, dan ekonomi. Untuk mencapai visi misi tersebut yayasan Arwaniyyah bekerjasama dengan mitra untuk mengelola tanah wakaf menjadi produktif melalui perkebunan, perdagangan, dan jasa. Keuntungan yang diperoleh dari produktivitas tersebut digunakan untuk kepentingan unit-unit lainnya (pesantren, madrasah, klinik, dIII).

Pendistribusian aset wakaf yang dilakukan yayasan Arwaniyyah saat ini terfokus pada kepemilikan aset berupa ruko, pabrik, maupun kantor. Bentuk produktivitas yang dilakukan adalah melalui keberpihakan pihak ketiga (investor) untuk ikut dalam pendayagunan aset wakaf. Hal tersebut dipertimbangkan karena beberapa faktor seperti lokasi tanah wakaf dan kondisi masyarakat sekitar.

1. Wakaf Usaha Perdagangan Untuk mendayagunakan aset wakaf menjadi wakaf usaha perdagangan, yayasan Arwaniyyah bekerjasama dengan pihak ketiga untuk menjadi distributor barang yang akan di perdagangkan di ruko atau toko milik yayasan Arwaniyyah. Salah satu distributor yayasan Arwaniyyah saat ini adalah darul fikr, Libanon yang mendistribusikan cetakan kitab-kitab klasik dan kontemporer. Selain itu, malalui Koperasi syariah yayasan Arwaniyyah bermitra dengan pedagang-pedagang kecil yang akan melakukan usaha dengan berbagai akad yang dapat dilakukan seperti mudharabah, murabahah, musyarakah, dan qiradl.

2. Wakaf Perusahaan

Yayasan Arwaniyyah menginvestasikan aset wakaf bekerjasama dengan pihak ketiga untuk pengadaan barang yang akan digunakan sebagai pabrik. Pengadaan peralatan pabrik tersebut didapatkan dari pihak ketiga dengan menggunakan akad murabahah yang nantinya akan menjadi aset wakaf. Hingga saat ini ada dua pabrik yang dikelola oleh yayasan Arwaniyyah, yaitu pabrik air mineral BUYA dan percetakan buya offset.

Hingga saat ini tanah wakaf yang dikelola oleh yayasan Arwaniyyah dibagibagi sesuai peruntukannya sebagai berikut:

Tabel 4.1

Aset Yayasan Arwaniyyah

\begin{tabular}{|l|l|l|}
\hline No & Peruntukan & $\begin{array}{l}\text { Luas } \\
\left(\mathrm{M}^{2}\right)\end{array}$ \\
\hline 1. & Ponpes MUSYQ & 3.752 \\
\hline 2. & $\begin{array}{l}\text { Ponpes Yanbu'ul } \\
\text { Qur'an Dewasa }\end{array}$ & 1.100 \\
\hline
\end{tabular}


Fahri, et al/Jurnal Ekonomi Syariah Teori dan Terapan Vol. 5 No. 8 Agustus 2018: 695-708;

STRATEGI MANAJEMEN PENGELOLAAN W
ARWANIYYAH KUDUS
\begin{tabular}{|l|l|l|}
\hline 3. & $\begin{array}{l}\text { Ponpes MUSYQ } \\
\text { Putri }\end{array}$ & 975 \\
\hline 4. & Madrasah & 24.093 \\
\hline 5. & Ruko & 207 \\
\hline 6. & $\begin{array}{l}\text { Pondok Tahfidz } \\
\text { Putri }\end{array}$ & 515 \\
\hline 7. & $\begin{array}{l}\text { Pondok Tahfidz } \\
\text { Remaja }\end{array}$ & 1.087 \\
\hline 8. & $\begin{array}{l}\text { Balai } \\
\text { Pengobatan Al } \\
\text { Fatah, } \\
\text { percetakan } \\
\text { BUYA Offset }\end{array}$ & 3.800 \\
\hline 9. & $\begin{array}{l}\text { Perkantoran dan } \\
\text { pabrik (Untuk } \\
\text { Usaha ekonomi) }\end{array}$ & 2.605 \\
\hline & Total & 38.134 \\
\hline
\end{tabular}

WAKAF PRODUKTIF DI PESANTREN YAYASAN

Data diolah

Tabel diatas merupakan rincian tanah wakaf yang dikelola oleh yayasan Arwaniyyah. Pengelolaan tanah wakaf sebagian besar (83\%) dikelola dalam bidang pendidikan (madrash dan pesantren) serta selebihnya dikelola dalam bidang ekonomi dan sosial.

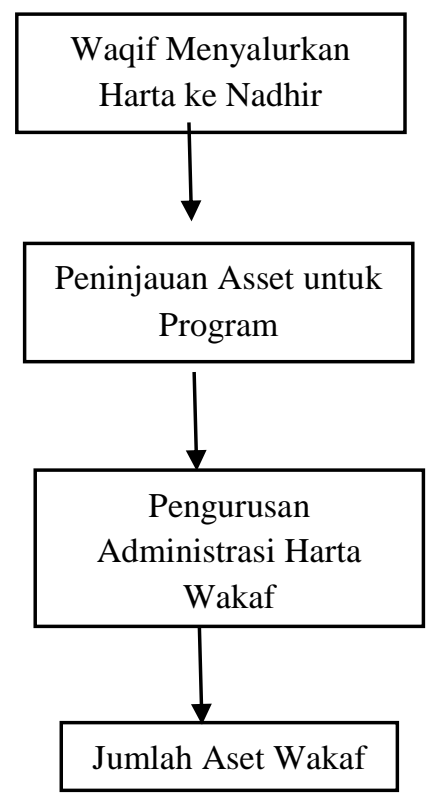

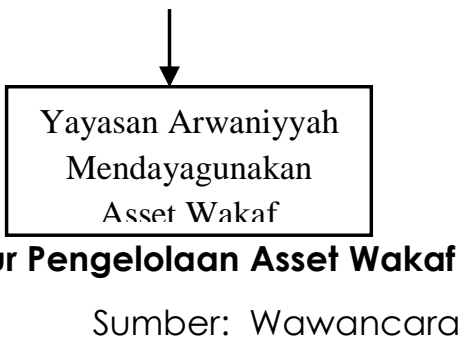

\section{Program Dari Aset Wakaf Untuk Kepentingan Umum}

Didalam rukun wakaf ada mauquf 'alaih (peruntukan wakaf) dimana wakif secara jelas harus menyebutkan peruntukan dan pemanfaatan harta wakaf kepada nadhir. Sebagai nadhir, yayasan Arwaniyyah mengarahkan peruntukan wakaf pada:

1. Pendidikan

2. Kesehatan

3. Pemberdayaan Ekonomi, atau

4. Menyerahkan pada nadhir

Untuk mencapai pada mauquf 'alaih tersebut pengelolaan harta wakaf yang dilakukan oleh yayasan Arwaniyyah adalah:

1. Program satu atap

Pesantren yang dibawah kendali yayasan Arwaniyyah selalu hanya terfokus pada program tahfidz dan ilmu salafiyyah. Pada tahun 2013 yayasan Arwaniyyah bekerja sama dengan kementrian agama mengelola tanah wakaf di Menawan untuk dibangunkan Madrasah tahfidz yang berorientasi pada intelektual sains. Melalui program ini yayasan Arwaniyyah memiliki cita-cita membentuk intelektual dan ilmuwan yang qur'aniy yang mampu bersaing di universitas-universitas ternama nantinya.

2. Markaz Lil Aitam "Utsman bin 'Affan 
Fahri, et al/Jurnal Ekonomi Syariah Teori dan Terapan Vol. 5 No. 8 Agustus 2018: 695-708;

\section{STRATEGI MANAJEMEN
ARWANIYYAH KUDUS}

Markaz lil aitam merupakn pondok pesantren tahfidz yang didirikan untuk anak-anak yatim piatu yang memiliki keinginan menghafalkan Al Qur'an. Para anak-anak yatim piatu mendapatkan beasiswa dari hasil pengelolaan harta wakaf yang masuk ke kas yayasan.

3. Klinik Umum Al Fatah

Klinik Al Fatah merupakan layanan kesehatan untuk para santri dan masyarakat umum disekitar pesantren. Klinik ini terus berkembang hingga mampu untuk menampung pasien yang membutuhkan rawat inap.

4. Kewirausahaan Bagi Santri

Beberapa aset wakaf yang dikelola oleh yayasn Arwaniyyah digunakan sebagai toko yang mampu memenuhi kebutuhan santri maupun masyarakat sekitar pesantren. Dengan adanya pelatihan kewirausahaan dalam mengelola unit bisnis diharapkan para santri mampu mandiri dalam ekonomi setelah lulus nantinya.

5. Pelatihan Gratis Bagi Karyawan

Pengelolaan aset wakaf menjadi produktif dengan didirikan pabrik dan kantor menjadikan lapangan usaha bagi masyarakat sekitar pesantren. Dalam perekrutan karyawan, yayasan Arwaniyyah memang memprioritaskan masyarakat sekitar. Namun, perekrutan tersebut haruslah sesuai dengan kebutuhan perusahaan untuk dapat terus memberikan profit bagi yayasan. Oleh sebab itu,mengikutkan karyawan ke pelatihan menjadi strategi penting yang dijalankan yayasan Arwaniyyah dalam mengembangkan usaha produktif melalui wakaf ini.

\subsubsection{Problematika Dalam Pengelolaan} Wakaf Produktif

Pengelolaan wakaf secara produktif masih terdengar asing dikalangan umat saat ini, tak terkecuali dikalangan pesantren sehingga problematika dalam pengelolaan wakaf produktif di lingkungan pesantren pasti ada. Di dalam manajemennya, yayasan Arwaniyyah memiliki problematika dalam pengelolaan wakaf produktif diantaranya :

1. Penghimpunan Dana

Yayasan Arwaniyyah merupakan yayasan berbasi pesantren salafiyyah bermadzhabkan syafi'iyyah yang selama ini tidak ada wakaf vang. Padahal wakaf vang merupakan hal penting dalam penghimpunan dana wakaf produktif karena dengan cara itu kebutuhan modal lebih mudah didapatkan. Namun, yayasan Arwaniyyah mampu menghimpun dana melalui pihak ketiga dalam mengelola wakaf produktif. Walaupun mampu mendatangkan pihak ketiga dalam menghimpun dana yayasan Arwaniyyah juga mengalami kendalakendala yang diakibatkan oleh beberapa hal, seperti :

A. Kurangnya

pemahaman masyarakat dalam kegiatan wakaf produktif apalagi BWI yang menjadi lembaga penyosialisasi wakaf produktif di Kudus baru berdiri pada tahun 2015.

B. Lokasi aset wakaf yang dikelola oleh yayasan Arwaniyyah terpencarpencar. 
Fahri, et al/Jurnal Ekonomi Syariah Teori dan Terapan Vol. 5 No. 8 Agustus 2018: 695-708; STRATEGI MANAJEMEN PENGELOLAAN WAKAF PRODUKTIF DI PESANTREN YAYASAN ARWANIYYAH KUDUS

2. Pendistribusian Dana

Adapun kendala pendistribusian harta wakaf yang dihadapi oleh yayasan Arwaniyyah diantaranya :

A. Birokrasi yang masih susah dilakukan karena badan wakaf Indonesia di kabupaten Kudus sendiri masih sangat muda.

B. Keuntungan yang didapat dari satu unit masih untuk menutupi kebutuhan unit lainnya.

\section{Analisis Manajemen Pengelolaan Wakaf Produktif di Yayasan Arwaniyyah}

Manajemen yang profesional dalam pengelolaan wakaf produktif dilakukan oleh yayasan Arwaniyyah dengan mitramitra yang terkait. Manajemen yang baik tersebut dilakukan untuk mencapai tujuan wakaf yang sesuai dengan visi misi yayasan. Dalam melakukan manajemen wakaf produktif, yayasan Arwaniyyah melakukan proses perencanaan, pengorganisasian, dan pengawasan.

\section{A. Perencanaan}

Dalam menjalankan suatu pekerjaan untuk mencapai sebuah tujuan, maka perencanaan merupakan strategi awal dalam suatu proses. Dalam hal ini Islam sangat memperhatikanya. Allah dalam menciptakan alam semesta ini dengan penciptaan yang matang dan tujuan yang begitu jelas.

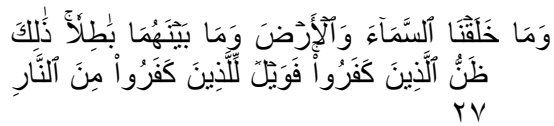
Artinya : "Dan kami tidak menciptakan langit dan bumi dan apa yang ada diantara keduanya secara sia-sia. Yang demikian itu merupakan anggapan orang-orang kafir. Maka celakalah orang-orang kafir masuk ke neraka.

Hafiduddin (2003,77-78) dalam Andika $(2015,7)$ menjelaskan bahwa dalam melakukan perencanaan ada beberapa aspek yang harus diperhatikan. Aspek tersebut antara lain :

1. Hasil yang ingin dicapai.

2. Orang yang akan melakukan

3. Waktu dan skala prioritas

4. Dana.

Dengan menilik hal tersebut proses planning atau perencanaan harus selalu dilakukan dalam mendayagunakan wakaf menjadi lebih produktif. Dengan sebuah perencenaan harta wakaf mampu memberikan manfaat dalam jangka panjang.

B. Pengorganisasian 
Fahri, et al/Jurnal Ekonomi Syariah Teori dan Terapan Vol. 5 No. 8 Agustus 2018: 695-708; STRATEGI MANAJEMEN PENGELOLAAN WAKAF PRODUKTIF DI PESANTREN YAYASAN ARWANIYYAH KUDUS

Organisasi menurut Amirullah dan Haris

Budiyono

$(2003,7)$

adalah

pengelompokan kegiatan untuk

mencapai tujua, termasuk di dalam ini

penetapan susunsan organisasi, tugas,

dan fungsinya. Agar pengelolaan wakaf

produktif dapat berjalan dengan efektif,

yayasan Arwaniyyah sebagai nadhir

pastinya memiliki sumber daya manusia

yang mengelola harta wakaf. Yayasan

Arwaniyyah dengan sumber daya

manusia yang dimilikinya membagi

mereka ke dalam tugas masing-masing.

Menjalankan sesuatu dengan

organisasi yang rapi dan teratur sangatlah

diperhatikan dalam ajaran Islam.

C. Pengawasan

Amirullah dan Haris Budiyono $(2003,7)$

mengartikan controlling atau

pengawasan sebagai penemuan dan

penerapan cara dan peralatan untuk

menjamin bahwa rencana telah

dilaksanakan sesuai dengan tujuan. Di

dalam Islam bentuk pengawasan yang

berasal dari diri sendiri ada karena

kekuatan iman dan tauhid karena

keyakinan bahwa seseorang akan selalu

diawasi oleh Allah SWT yang nanti akan dimintakan pertanggung jawaban di akhirat kelak.

\section{SIMPULAN}

Pada bab ini penulis akan memaparkan kesimpulan dari penilitian yang berdasarkan pada hasil pembahasan yang telah dijelaskan. Kesimpulan tersebut antara lain:

1. Yayasan Arwaniyyah menggalang harta wakaf yang didapatkan dari warga dan jamaah yang mereka miliki. Tanah atau aset wakaf yang mereka miliki didayagunakan ke dalam tiga bidang, agama, pendidikan, dan sosial ekonomi. Dalam bidang agama harta wakaf dikelola menjadi masjid yang mampu memberikan pengajian Al Qur'an serta memiliki jama'ah dalam thoriqot naqsabandiyyah. Dalam bidang pendidikan yayasan Arwaniyyah mengelola wakaf pada pembangunan madrasah dan pesantren tahfidz. Pada bidang ekonomi dan sosial yayasab Arwaniyyah mengelola tanah wakaf menjadi produktif dengan membangun pabrik air mineral, kantor, dan ruko.

2. Tanah wakaf dikelola oleh yayasan Arwaniyyah menjadi aset produktif dalam pemberdayaan unit-unit usaha peroduktif seperti pembuatan pabriak air mineral, percetakan, dan ruko telah mampu dikelola secara baik sehingga memberikan lapangan kerja dan kepedulian bagi masyarakat sekitar yang dapat menjadi sumber pendapatan bagi masyarakat. Namun, laporan keuangan yang dikelola terutama untuk hasil atau 
Fahri, et al/Jurnal Ekonomi Syariah Teori dan Terapan Vol. 5 No. 8 Agustus 2018: 695-708; STRATEGI MANAJEMEN PENGELOLAAN WAKAF PRODUKTIF DI PESANTREN YAYASAN

\section{ARWANIYYAH KUDUS}

pendapatan unit-unit usaha masih belum dilakukan oleh yayasan Arwaniyyah secara baik dan akuntabel.

\section{Daftar Pustaka}

Al Qur'an. Departemen Agama Republik Indonesia. Syamil Qur'an The Miracle 15 in 1. 2009. Bandung: PT Sygma Examedia Arkanleema.

Al Hajjaj, Abu Al Husain Muslim bin. 2015. Shohih Muslim. Offline. Maktabah Syamilah.

Abdullah, Andika Rahmad. Manajemen Wakaf Produktif: Studi Pengelolaan Donasi Wakaf Bagi Pemberdayaan Ekonomi Umat Pada Dompet Dhuafa Republika. Jurnal Ekonomi UIN Malang. Online. (http:///etheses.uinmalang.ac.id/2522/12/19510109_Rin gkasan.pdf, diakses pada 9 November 2016. Fakultas Ekonomi Univeristas Islam Negeri Malang.

Al Bajuri, Syeikh Ibrahim. Hasyiah Al Bajuri 'ala Ibnu Qosim Al Ghuzzi. Jakarta: PT Karya Insani.

Al Bujairomi, Sulaiman bin Muhammad. 2015. Bujairomi 'alaa al Khatib. Offline. Maktabah Syamilah.

Al Hasani, Muhammad Ar Rouf Qosimiy. 2007. At Tathwiir At Takhrijiy wa At Tasyri'i li An Nidzomi Al Waqfi : Numudzujil latishodi At Tazommuniy. Jordan: Chasier du CREAD.

Amirullah dan Haris budiyono, 2003. Pengantar Manajemen. Yogyakarta: Graha IImu.
Antonio, Muhammad Syafi'i Bank Syari'ah dari Teori ke Praktek. Jakarta: Gema Insani Prss dan Tazkia Cendekia.

As Shan'ani, Muhammad Ibnu Isma'il. Subulus Salam. Mesir : Mushtafa Bab al Halabiwa Awladuh.

At Thanthawi, Muhammad Sayyid 2013. Tafsir Al Wasith lit Thanthawi. Online. Al Mausu'ah As Syamilah.

Dahwan. 2008. Pengelolaan Benda Wakaf Produktif. Jurnal UIN Sunan Kalijaga. Online. (http://digilib.uinsuka.ac.id/8240/1/DAHWAN\%2OPEN GELOLAAN\%20BENDA\%20WAKAF\%20 PRODUKTIF..pdf, diakses pada 7 November 2016. Fakultas Ekonomi Universitas Islam Sunan Kalijaga Yogyakarta.

Departemen Agama. 2003. Fiqh Waqf. Jakarta: Direktorat Pemberdayaan Wakaf Direktorat Jendral Bimbingan Masyarakat Islam Departemen Agama Rl.

Departemen Agama. 2005. Pola Pengembangan Pondok Pesantren. Direktorat Pendidikan dan Pondok Pesantren Departemen Agama RI.

Emzir. 2012. Metodologi Penelitian Kualitatif: Analisis Data. Jakarta: PT. Raja Grafindo Persada.

Jawad Mughniyah. 1996. Fiqih Lima Madzhab: Edisi Lengkap. Jakarta: PT. Lentera Basrita.

Wadjijiy, Farid dan Mursyid. 2007. Wakaf dan Kesejahteraan Umat "Filantropi yang Hampir Terlupakan". Yogyakarta: Pustaka Pelajar 
Fahri, et al/Jurnal Ekonomi Syariah Teori dan Terapan Vol. 5 No. 8 Agustus 2018: 695-708; STRATEGI MANAJEMEN PENGELOLAAN WAKAF PRODUKTIF DI PESANTREN YAYASAN ARWANIYYAH KUDUS

Moleong, Lexy J. 2005. Metodologi

Pemberdayaan Ekonomi Pesantren

Penelitian Kualitatif, rev. Ed. IStudi pada Pondok Pesantren At Bandung: PT. Remaja Rosdakarya.

Mubarak, Jaih. 2008. Wakaf Produktif. Bandung: Simbiosa Reksatama.

Noor, Mahpuddin, H. 2006. Potret Dunia Pesantren. Bandung: Humaniora.

Qomar, Mujamil. 2008. Pesantren: Dari Transformasi Metodologi Menuju Demokrasi Institusi, Jakarta: Erlangga. Tauhid Al-Islamy Magelang). Tesis. Yogyakarta: Program Pascasarjana Universitas Islam Negeri Sunan Kalijaga.

Sugiyono. 2014. Memahami Penelitian Kualitatif. Bandung: Alfabeta.

Yin, Robert K. 2008. Studi Kasus:Desain dan Metode. Jakarta: PT. Raja Grafindo Persada.

Saadati, Nila. 2014. Pengelolaan Wakaf Tunai dalam Mekanisme 